\title{
Heading south or north: novel insights on European silver eel Anguilla anguilla migration in the North Sea
}

\author{
Jeroen Huisman ${ }^{1,2, *}$, Pieterjan Verhelst ${ }^{3,4,5,6, *, * *}$, Klaas Deneudt ${ }^{5}$, Peter Goethals ${ }^{6}$, \\ Tom Moens ${ }^{3}$, Leopold A. J. Nagelkerke ${ }^{1}$, Carsten Nolting ${ }^{7}$, Jan Reubens ${ }^{3,5}$, \\ Peter Paul Schollema ${ }^{8}$, Hendrik V. Winter ${ }^{9}$, Ans Mouton ${ }^{4,6}$ \\ ${ }^{1}$ Wageningen Institute of Animal Sciences, Wageningen University and Research Centre, De Elst 1, 6708 WD Wageningen, \\ The Netherlands \\ ${ }^{2}$ Research group Marine and Coastal ecology and management, Van Hall Larenstein Applied Sciences University, Agora 1, \\ 8934 CJ, Leeuwarden, The Netherlands \\ ${ }^{3}$ Research group Marine Biology, Ghent University, Krijgslaan 281, 9000 Ghent, Belgium \\ ${ }^{4}$ Research Institute for Nature and Forest (INBO), Kliniekstraat 25, 1070 Brussels, Belgium \\ ${ }^{5}$ Flanders Marine Institute, Wandelaarkaai 7, 8400 Ostend, Belgium \\ ${ }^{6}$ Laboratory of Environmental Toxicology and Aquatic Ecology, Ghent University, Jozef Plateaustraat 22, 9000 Ghent, Belgium \\ ${ }^{7}$ Country Fisheries Association Westphalia and Lippe, Sprakeler Str. 409, 48159 Münster, Germany \\ ${ }^{8}$ Water Authority Hunze en Aa's, Aquapark 5, 9641 PJ Veendam, The Netherlands \\ ${ }^{9}$ IMARES, Wageningen University and Research, PO Box 68 IJmuiden, 1970 AB, The Netherlands
}

\begin{abstract}
The European eel Anguilla anguilla L. is a critically endangered fish species that migrates from coastal and freshwater habitats to the Sargasso Sea to spawn. However, the exact migration routes and destination of European eel are still unknown. We are the first to observe southward migrating silver eels in the North Sea. Eels were tagged with acoustic transmitters in 3 different river catchments in Western Europe and swam to the Dutch-Belgian coastal zone during their spawning migration. Therefore, at least part of the Western European population of eels migrates towards the English Channel, in contrast with the Nordic migration route hypothesis. This different migratory route may affect the energy reserve available for spawning and therefore the contribution of these eels to the population. As such, increasing our knowledge of marine eel migrations contributes to the goal of achieving sustainable eel stock management.
\end{abstract}

KEY WORDS: European eel $\cdot$ Marine migration $\cdot$ Telemetry $\cdot$ Conservation

Resale or republication not permitted without written consent of the publisher

\section{INTRODUCTION}

The European eel Anguilla anguilla L. is a facultative catadromous fish species with a complex life cycle, and despite extensive research, many questions still remain unanswered (e.g. what migration routes do they take, how do they orient themselves, what is the mortality rate during the marine migration stage) (Tesch 1977). As it is listed as Critically Endangered on the IUCN Red List, there is an urgent need to conserve the species. To help restore the European eel population, the European commission issued the European Eel Regulation (Council Regulation [EC] No. 1100/2007), stating that European 
countries should allow $40 \%$ escapement of silver eels (i.e. the life stage of maturing eels migrating to the spawning area in the Sargasso Sea) from inland waters to the sea. To meet this goal, countries have taken actions and implemented measures such as restrictions to fisheries, restocking and remediation of migration barriers. However, due to technical inabilities to track silver eels, migration routes and migratory behaviour remain largely unknown.

As eels only spawn once and do not feed during migration (Tesch 1977, Chow et al. 2010), they must rely on their fat reserves for both migration and spawning. It is therefore generally assumed that silver eels take the energetically most favourable migration route to their spawning grounds (van Ginneken \& van den Thillart 2000). Experts tend to agree on the Nordic migration route hypothesis, which states that European eels from Northern Europe migrate northward in the North Sea, passing the British Isles, after which they reach the Atlantic Ocean (Tesch 1979) (Fig. 1). Acoustic telemetry studies conducted in the German Bight demonstrated that silver eels released at sea swim northwestward (Tesch 1992, Tesch \& Rohlf 2003). Research in the Baltic yielded similar results, indicating that silver eels migrate in a southwestern direction to exit the Baltic Sea, after which they migrate in a northwestern direction towards Scotland (Westerberg 1979, Karlsson 1984). More recently, the Nordic route was confirmed by a study in Sweden using pop-up satellite archival transmitters (PSATs) (Westerberg et al.

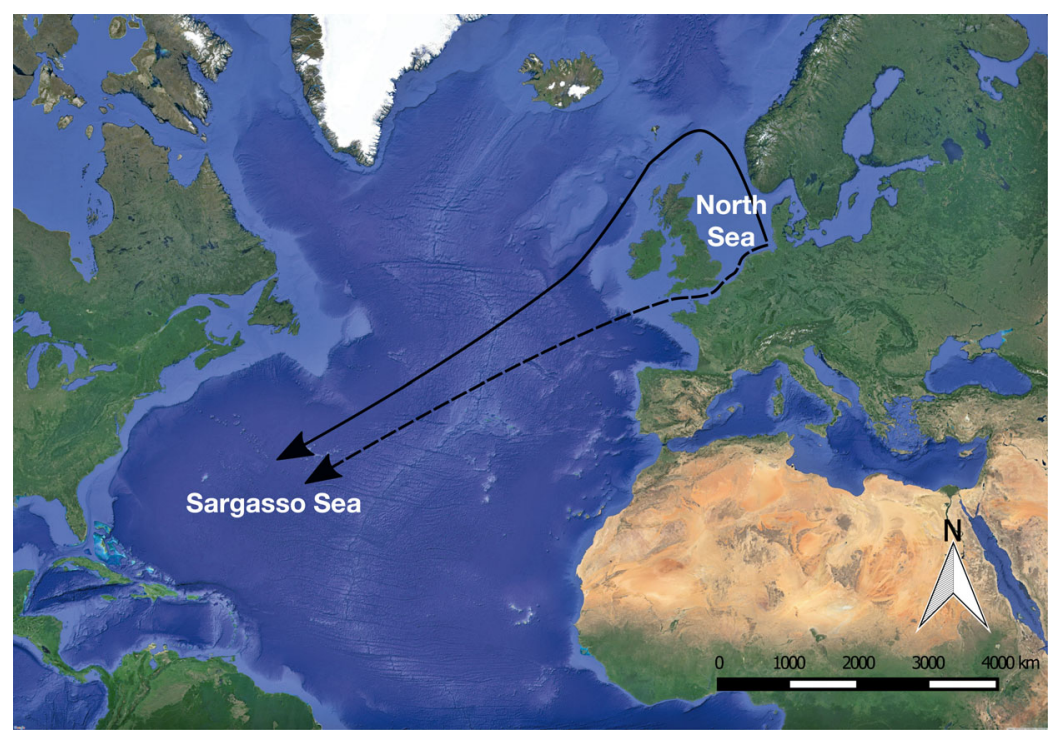

Fig. 1. Possible silver eel migration routes from western and northeastern Europe. Solid line: Nordic migration route based on Tesch (1979) and Westerberg et al. (2014); dashed line: southwestern migration routes through the English Channel based on the results of the present study
2014). Although orientation by an imprinted map is unlikely (Westerberg et al. 2014), the reason for the directional choice of the Nordic migration route is still under debate: the most frequently presented explanations are geomagnetism, flow detection, olfactory orientation and sense of depth (Tesch 1974).

Despite the plausibility of the Nordic migration route hypothesis, this route has not been confirmed for silver eels migrating from Western European tributaries to the Sargasso Sea. For these eels, an alternative and shorter route would be through the English Channel (the sea between southern England and northern France) (Fig. 1). So far, research on marine silver eel migration has been carried out on eels artificially displaced displacement from freshwater environments into the sea (Westerberg et al. 2007, Aarestrup et al. 2009, Béguer-Pon et al. 2015, Wysujack et al. 2015), or mainly focused on deep coastal zones and open oceans, but many migrating silver eels also have to cross large shallow tidal seas. The knowledge gap on migratory routes and behaviour in these systems deserves further attention, especially in coastal regions, which are often heavily impacted by anthropogenic disturbances.

We explored European silver eel migration by acoustic telemetry in a shallow sea, i.e. the North Sea. Cooperation between separate projects in Belgium, Germany and The Netherlands allowed us to cover a wide geographical range of this species. The results provide novel insights into the marine migration routes and behaviour of European eel, which may contribute to a more efficient conservation of the species; the results also emphasize the importance of international cooperation in order to address these large-scale fish migration issues.

\section{MATERIALS AND METHODS}

\section{General methodology}

This study was based on detections of tagged eels from the LifeWatch observatory, which installed a permanent acoustic network at the DutchBelgian coast (www.lifewatch.be/en/ fish-acoustic-receiver-network) (Fig. 2). The detected eels were tagged for other independent projects focusing on eel migration at migration barriers and in altered river systems. The pro- 


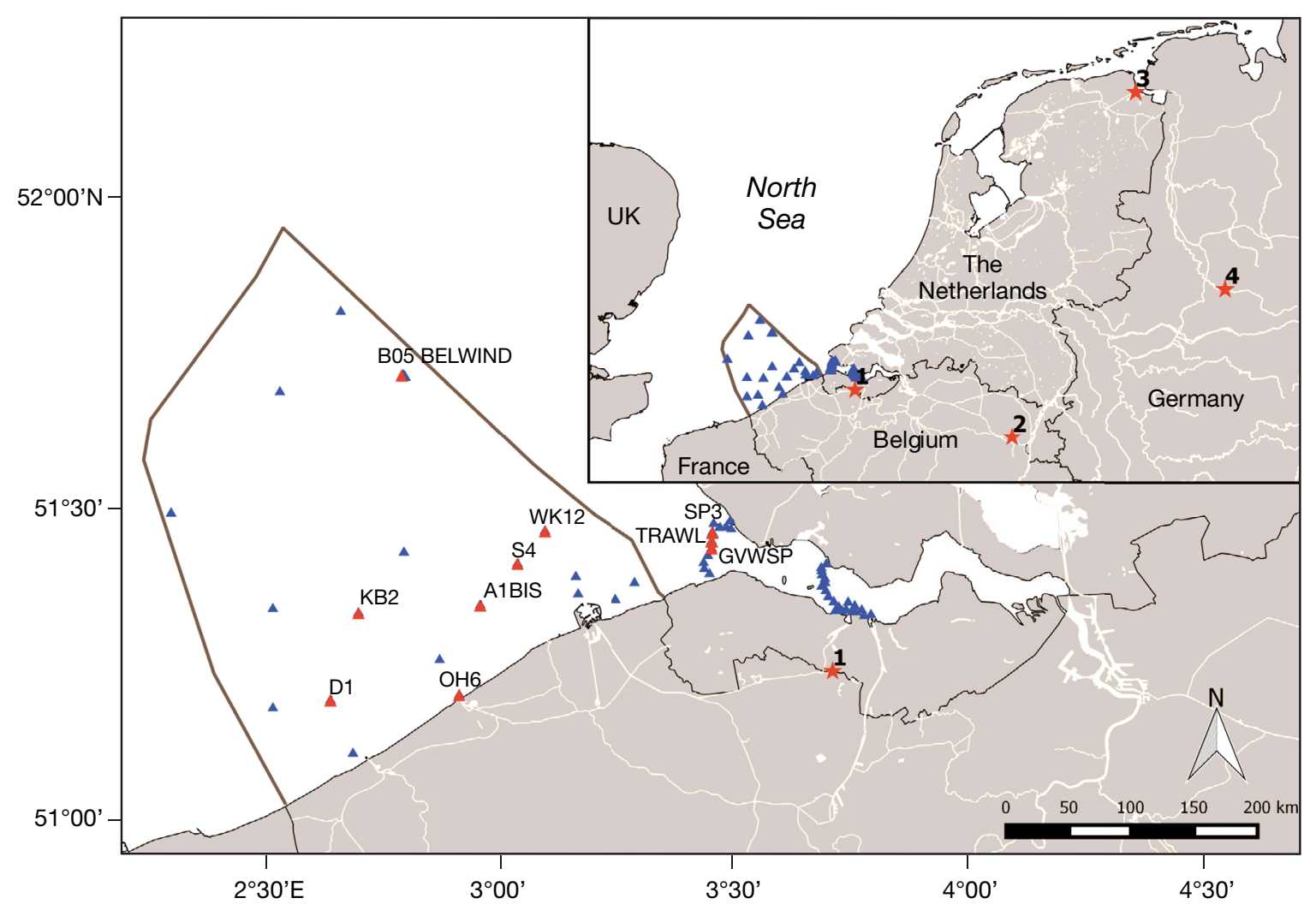

Fig. 2. LifeWatch acoustic telemetry network in the Scheldt Estuary and Belgian part of the North Sea. The triangles are acoustic listening stations (ALS) deployed on marine buoys. Eels were detected at red triangles, of which the buoy name is given. Asterisks indicate release locations of the tagged eels: (1) Boekhoute (Zwartesluisbeek, Scheldt catchment); (2) Genk

(Albert Channel, Meuse catchment); (3) Delfzijl (Ems Channel, Ems catchment); (4) Einen (Ems River, Ems catchment)

jects used identical acoustic telemetry, which provided the opportunity to investigate marine silver eel migration routes. In 4 different projects, eels were caught in fresh water, tagged and released at their catch location (see Fig. 2, Table S1 in the Supplement at www. int-res.com/articles/suppl/m554p257_supp.pdf). The studies were conducted in 3 different catchments in Western Europe: 2 in the Ems catchment, one in the Scheldt catchment and one in the Meuse catchment. Although the aim of the original projects differed, it was the observations at marine detection stations of these tagged eels that were used for this study.

\section{Description of experiments}

Within the framework of the LifeWatch observatory, a permanent acoustic network of 54 automatic listening stations (ALS) (VR2W, VEMCO) has been operational since the spring of 2014 in the Scheldt Estuary (33 ALSs) and the Belgian part of the North Sea (BPNS) (21 ALSs). The ALSs are moored at strategic locations to maximise the probability of detection (see Fig. 2): 2 arrays in the Scheldt Estuary to detect incoming and outgoing fish, and a scattered pattern in the BPNS (since it is impossible to cover the whole area). The network in the BPNS focuses on the nearshore region, as most of the eels were expected there. ALSs were moored at navigational buoys with stainless steel chains ca. $4 \mathrm{~m}$ long, weighing ca. $17.5 \mathrm{~kg}$. ALSs were attached to the chain with stainless steel clamping rings, with the hydrophone directed downwards (Fig. S1 in the Supplement).

As stated previously, in this study we used information from a number of independent experiments in which eels were tagged. In the summer of 2012, we tagged 73 eels at a polder area in Boekhoute (Scheldt catchment, Belgium) to investigate the effect of a pumping station on silver eel mortality and behaviour during downstream migration (Buysse et al. 2015). In 2013 and 2014, we tagged a total of 60 eels at the Albert Channel in Genk (Meuse catchment, Belgium) to investigate silver eel migration in relation to sluices and anthropogenically influenced 


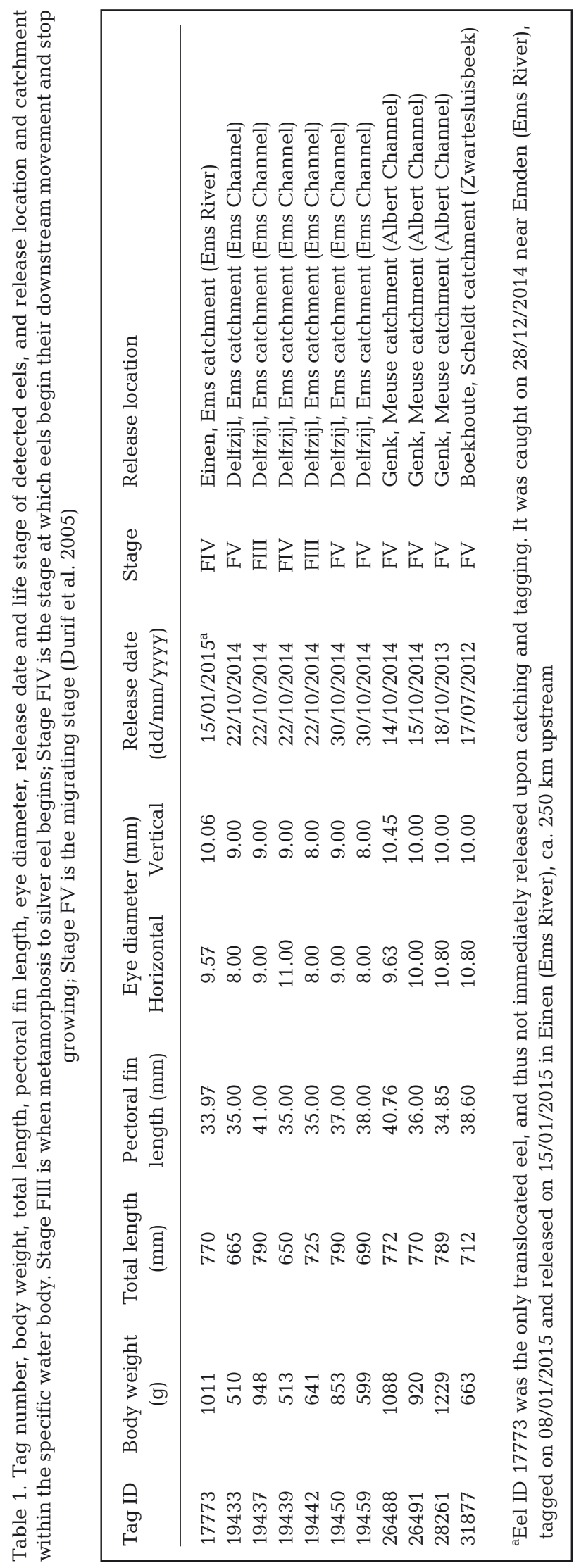

hydrology. In December 2014, we caught 185 eels in the Ems river near Emden (Ems catchment, Germany) and upon tagging, we translocated these eels approximately $250 \mathrm{~km}$ upstream to Einen to compare migratory behaviour of silver eels in the Western German Channel System versus that in the River Ems. In autumn 2014, we tagged 40 eels at a polder area in Delfzijl (Ems catchment, The Netherlands) to explore silver eel migratory behaviour and investigate the efficiency of an intertidal fish pass at a pumping station. To determine the maturation stage of all tagged eels according to Durif et al. (2005), total length (to the nearest $\mathrm{mm}$ ), body weight (to the nearest $\mathrm{g}$ ), average eye diameter (to the nearest $\mathrm{mm}$ ) and length of the pectoral fin (to the nearest $\mathrm{mm}$ ) were measured (Table 1). Silver eels were tagged with coded acoustic transmitters (V9 and V13, VEMCO) following Baras \& Jeandrain (1998) and released at their catch location, except for the 185 eels caught near Emden (see above). Additional information about the tags and methods of capture can be found in Table S1 in the Supplement.

Detection time of individual eels at an ALS was related to sunrise, sunset and tides. Sunrise and sunset data were obtained from the Astronomical Applications Department of the US Naval Observatory (http://aa.usno.navy.mil/index.php). Modelled tidal data were obtained from the Royal Belgian Institute of Natural Sciences, Operational Direction Natural Environment (KBIN-OD Nature).

\section{RESULTS AND DISCUSSION}

\section{Migratory routes and activity}

Between 25 October 2014 and 17 October 2015, 11 eels were detected at the marine acoustic network; 7 originating from the Ems catchment ( 6 from The Netherlands and 1 from Germany), 3 from the Meuse catchment (Belgium) and 1 from the Scheldt catchment (Belgium) (Fig. 2, Table 1). Of the 40 eels tagged in the polder area at Delfzijl (The Netherlands), 30 migrated successfully to sea as they were detected at an ALS on the seaside of the pumping station. Of these 30 eels, $6(20 \%)$ were detected at the Dutch-Belgian coast and hence migrated southwards. In the Albert Channel (Belgium), 3 of the 60 eels migrated to sea and all 3 were detected $(100 \%)$. Of the 73 eels tagged in the polder area at Boekhoute (Belgium), 2 migrated to sea, 1 of which (50\%) was detected at the marine acoustic network. Although 93 of the 185 tagged eels in Einen (Germany) 
reached the North Sea, only one $(\leq 1 \%)$ was detected in the BPNS. The reason can only be speculated, but it is possible that some of these eels took the Nordic migration route (Westerberg et al. 2014) or resided in the Ems until conditions became more favourable to proceed their migration. Migratory eels have indeed been observed to undergo a resident stage in the lower part of rivers and estuaries (Aarestrup et al. 2008). Given the vast area of the North Sea, these detection rates are high and indicate a route that may well be chosen by a larger part of the eel population.

Our results are the first to show a southwest oriented migration route of silver eels emigrating from 3 different Western European catchments, heading to the English Channel in order to exit the North Sea on their way to the Sargasso Sea. This is in contrast with the Nordic migration route hypothesis, and demonstrates that at least some of the Western European eels take another route. Moreover, we present results on eels that were tagged in freshwater and released on-site, in contrast to previous studies (Tesch 1974, 1979, 1992, Aarestrup et al. 2009, Wysujack et al. 2015) in which eels were translocated from freshwater habitats to the sea. It is not clear if translocation affects eel behaviour, but allowing them to emigrate naturally avoids this potential bias.

Eels were only detected from mid-October until early February; no detections were obtained between March and October 2015. Ten eels were detected less than $20 \mathrm{~km}$ offshore, whereas only one was approximately $50 \mathrm{~km}$ offshore. It should be noted that 15 out of 21 ALSs in the BPNS are located within $30 \mathrm{~km}$ offshore, which could explain why the majority of eels was detected within this zone. Ten eels were detected at single ALSs only, but all of them at different locations in the BPNS. These eels were each detected less than 10 times by an ALS and always within a single hour, indicating that they were migrating through the detection field without residing there for longer periods. Only 1 eel was detected by 4 different ALSs, 3 of which were located at the mouth of the Scheldt Estuary and one in the BPNS.

\section{Swim speed}

Marine migration speed was calculated for the 6 eels from Delfzijl, 1 eel from Boekhoute and 1 eel from Genk that migrated via the Scheldt Estuary since these eels were detected at the channel mouths at sea (see Table S2 in the Supplement). The other 2 eels from Genk and one from Einen were not detected at the river mouths, since no ALSs were present in that area. As migration behaviour in freshwater and the marine environment might differ considerably (e.g. retention periods resulting in an overestimation of swim speed), the swim speeds of the latter 3 eels will not be discussed. We found a mean $( \pm \mathrm{SD})$ swim speed of $20 \pm 4.5 \mathrm{~km} \mathrm{~d}^{-1}$ (range: 12 to $25 \mathrm{~km} \mathrm{~d}^{-1}$ ) for the eels from Delfzijl and $24 \mathrm{~km} \mathrm{~d}^{-1}$ for the eel from Boekhoute. Such swim speeds are in accordance with Westerberg et al. (2014). The eel from Genk migrated at a speed of only $1 \mathrm{~km} \mathrm{~d}^{-1}$, which is probably due to a retention period in the Scheldt Estuary (Aarestrup et al. 2008).

\section{Diurnal activity and flow-related migration patterns}

Seven eels were detected at night, 3 during daytime and 1 eel was detected during both day and night. This is roughly in accordance with the general assumption that eels migrate at night to avoid predators (Westerberg et al. 2007). However, a recent study documented eel migration during both day and night (Wysujack et al. 2015). Moreover, diurnal migratory behaviour in the North Sea may also be affected by high turbidity.

The tidal action in the North Sea results in a change of flow direction twice per day. As such, the southward ebb tidal flow is directed towards the English Channel twice per day, whereas the net residual flow over the tides is directed northwards. The majority of the eels $(73 \%)$ were detected during a southward tidal flow (Table S2). This suggests that eels selectively use tidal flow in the North Sea to migrate in an energetically favourable way, a behaviour known as selective tidal stream transport: a fish ascends into the water column when the transporting tide is in the preferred direction and descends to the bottom to maintain its position in the opposing tidal current. Selective tidal stream transport has been documented for both the European eel (McCleave \& Arnold 1999) and the American eel (Parker \& McCleave 1997, Béguer-Pon et al. 2014). The application of PSATs in further research could provide more insight into this issue.

\section{CONCLUSIONS}

Our results provide strong evidence that at least part of the Western European population of silver eels migrate southwestward in the North Sea and use the English Channel as a migration route. Moreover, 
we have shown that at least some eels from different catchments in Belgium, Germany and The Netherlands use this migration route. Our results also suggest that eels are predominantly active at night and selectively use tidal flow to migrate. This study highlights that acoustic telemetry is an effective technique to track eels over large distances, and in coastal marine environments. However, to answer questions about the migratory behaviour of European eel in the Atlantic Ocean, other techniques such as PSATs may be better suited. Further research on migration routes and behaviour could help resolve the question of how many of the silver eels escaping to sea actually reach the spawning ground and effectively contribute to recruitment. Furthermore, different migration routes may have different bio-energetic implications: some routes may be energetically more demanding, leaving less energy for spawning. As such, management might need to focus more on areas where eels take an energetically favourable route and contribute more to spawning. However, we do not have enough information yet to determine whether something significant is happening during marine migration and whether the inland management actions taken are effective. To further clarify migration behaviour of diadromous fish in the marine phase, transnational cooperation and investment in large-scale marine detection arrays (which enable the study of migration routes and behaviour) are needed, and could be instrumental in the conservation of diadromous fish species in general, and European eel in particular.

Acknowledgements. P.V. holds a doctoral grant from the Flemish Agency for Innovation by Science and Technology (IWT). J.B.J.H. is funded by the Van Hall Larenstein Applied Sciences University and the Wageningen University Institute of Animal Sciences. This work was supported by data and infrastructure provided by the LifeWatch ESFRI observatory and the research was further supported by the Dutch project 'Ruim Baan Voor Vissen' and the European Fisheries Fund (EFF). We thank DAB VLOOT and Rijkswaterstaat for their cooperation and permission to use their marine buoys. We also thank the Royal Belgian Institute of Natural Sciences, Operational Direction Natural Environment (KBINOD Nature), for the BPNS flow direction data.

\section{LITERATURE CITED}

Aarestrup K, Thorstad EB, Koed A, Jepsen N and others (2008) Survival and behaviour of European silver eel in late freshwater and early marine phase during spring migration. Fish Manag Ecol 15:435-440

Aarestrup K, Økland F, Hansen MM, Righton D and others (2009) Oceanic spawning migration of the European eel (Anguilla anguilla). Science 325:1660
Baras E, Jeandrain D (1998) Evaluation of surgery procedures for tagging eel Anguilla anguilla (L.) with biotelemetry transmitters. Hydrobiologia 371/372:107-111

Béguer-Pon M, Castonguay M, Benchetrit J, Hatin D and others (2014) Large scale migration patterns of silver American eels (Anguilla rostrata) from the St. Lawrence River to the Gulf using acoustic telemetry. Can J Fish Aquat Sci 71:1579-1592

Béguer-Pon M, Castonguay M, Shan S, Benchetrit J, Dodson JJ (2015) Direct observations of American eels migrating across the continental shelf to the Sargasso Sea. Nat Commun 6:8705

Buysse D, Mouton AM, Baeyens R, Coeck J (2015) Evaluation of downstream migration mitigation actions for eel at an Archimedes screw pump pumping station. Fish Manage Ecol 22, 286 - 294

> Chow S, Kurogi H, Katayama S, Ambe D and others (2010) Japanese eel Anguilla japonica do not assimilate nutrition during the oceanic spawning migration: evidence from stable isotope analysis. Mar Ecol Prog Ser 402:233-238

Durif C, Dufour S, Elie P (2005) The silvering process of Anguilla anguilla: a new classification from yellow resident to the silver migrating stage. J Fish Biol 66:1025-1043

Karlsson L (1984) Migration of European silver eels, Anguilla anguilla. PhD dissertation, Uppsala University

McCleave J, Arnold G (1999) Movements of yellow- and silver-phase European eels (Anguilla anguilla L.) tracked in the western North Sea. ICES J Mar Sci 56:510-536

Parker SJ, McCleave JD (1997) Selective tidal stream transport by American eels during homing movements and estuarine migration. J Mar Biol Assoc UK 77:871-889

Tesch FW (1974) Speed and direction of silver and yellow eels, Anguilla anguilla, released and tracked in open North Sea. Ber Dtsch Wiss Komm Meeresforsch 23: 181-197

Tesch FW (1977) The eel: biology and management of anguillid eels. Chapman \& Hall, London

Tesch FW (1979) Tracking of silver eels (Anguilla anguilla L.) in different shelf areas of the Northeast Atlantic. Rapp P-V Réun Cons Int Explor Mer 174:104-114

Tesch FW (1992) Insignificance of tidal currents for silver eel migration as studied by eel tracking and current measurements. Ir Fish Invest Ser A (Freshw) 36:105-109

Tesch FW, Rohlf N (2003) Migration from continental waters to the spawning grounds. In: Aida $\mathrm{K}$, Tsukamoto $\mathrm{K}$, Yamauchi K (eds) Eel biology. Springer, Heidelberg, p 223-236

> van Ginneken VJT, van den Thillart GEEJM (2000) Eel fat stores are enough to reach the Sargasso. Nature 403: 156-157

Westerberg H (1979) Counter-current orientation in the migration of the European eel. Rapp P-V Réun Cons Int Explor Mer 174:134-143

Westerberg H, Lagenfelt I, Svedäng H (2007) Silver eel migration behaviour in the Baltic. ICES J Mar Sci 64: 1457-1462

> Westerberg H, Sjöberg N, Lagenfelt I, Aarestrup K, Righton D (2014) Behaviour of stocked and naturally recruited European eels during migration. Mar Ecol Prog Ser 496: 145-157

> Wysujack K, Westerberg H, Aarestrup K, Trautner J, Kurwie T, Nagel F, Hanel R (2015) The migration behaviour of European silver eels (Anguilla anguilla) released in open ocean conditions. Mar Freshw Res 66:145-157

Submitted: January 25, 2016; Accepted: June 10, 2016

Proofs received from author(s): July 17, 2016
Editorial responsibility: Jake Rice,

Ottawa, Ontario, Canada 